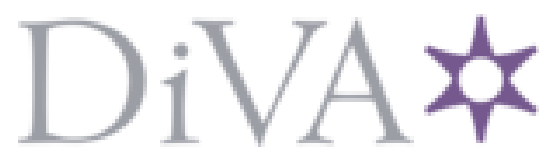

http://www.diva-portal.org

\title{
Postprint
}

This is the accepted version of a chapter published in Theoretical perspectives on family businesses.

Citation for the original published chapter:

Kallmuenzer, A. (2015)

Agency theory and the family business.

In: Mattias Nordqvist, Leif Melin, Matthias Waldkirch and Gershon Kumeto (ed.), Theoretical perspectives on family businesses (pp. 58-77). Cheltenham: Edward Elgar Publishing https://doi.org/10.4337/9781783479665.00011

N.B. When citing this work, cite the original published chapter.

Permanent link to this version:

http://urn.kb.se/resolve?urn=urn:nbn:se:hj:diva-34241 


\section{Agency Theory and the Family Business}

\section{Andreas Kallmuenzer}

\section{Introduction}

The conceptual domain of agency theory is one of the dominant organisational theory perspectives applied in current family business research (Chrisman, Kellermanns, Chan, \& Liano, 2010). According to agency theory (Jensen \& Meckling, 1976), agency costs generally arise due to individuals' self-interest and decision making based on rational thinking and oriented toward own preferences. With more people involved in decision-making, such as through the separation of ownership and management, agency costs occur due to different preferences and information asymmetries between the owner (principal) and the employed management (agent) (Jensen \& Meckling, 1976). In other words, agents take decisions based on their individual preferences (e.g., short-term, financial gains) instead of the owners' preferences (e.g., long-term, sustainable development).

For family firms, it is often assumed that ownership and management are aligned within the same family or even the same person (Chua, Chrisman, \& Sharma, 1999; Litz, 1995). According to Jensen and Meckling (1976), this alignment would lead to the avoidance of agency costs. However, the influence of family-related issues aside from business interests in family firms (Nordqvist, Habbershon, \& Melin, 2008) creates a more complex structure of individual preferences (Chrisman, Chua, \& Litz, 2004; Corbetta \& Salvato, 2004; GómezMejía, Núñez-Nickel, \& Gutierrez, 2001; Sharma, Chrisman, \& Chua, 1997). Relational and altruistic aspects play an important role in decision-making and so create other sources of agency costs (Mustakallio, Autio, \& Zahra, 2002; Poppo \& Zenger, 2002; Schulze, Lubatkin, Dino, \& Buchholtz, 2001). Thus, agency theory is considered to be a highly relevant 
perspective in family business research that aids in better understanding particular aspects of the behaviour of actors in family firms.

This chapter aims to elucidate relevant research about the agency perspective, from its origin in financial research to its application and adaptation in family business research. This chapter proposes that the heterogeneity of family firms influences the creation of agency costs. Furthermore, it suggests that agency costs moderate the influence of entrepreneurial attitudes on performance. Finally, it improves the knowledge of how to structure contractual relationships and monitoring mechanisms in family firms to reduce agency costs.

The chapter is structured as follows. First, an overview of agency theory is presented. Second, its use in prior family business research is displayed, which includes a theoretical delimitation, branches of the theory and major contributions. Third, it argues for the relevance of agency theory for future family business research and practice. The chapter concludes with implications for the general management discipline and limitations.

\section{Overview of agency theory}

Agency theory is primarily applied in the prior literature when the problems of cooperative structures are investigated (Eisenhardt, 1989). The theory helps to understand problems of cooperation, such as asymmetric information, uncertain outcomes, the question of the usability of incentives, and the identification of risks in decision-making. The agency theory framework has its origin in financial research within economic theory (Jensen \& Meckling, 1976). Also known as the principal-agent paradigm, agency theory emphasises the contractual problem between a firm's principal, generally the owner, and a firm's agents, employed executives that control the use of resources. Due to a conflict of preferences, this separation of ownership and control can result in agency costs resulting from a need to align interests 
through monitoring or contractual solutions. As a logical consequence, Jensen and Meckling (1976) argue that agency costs are omitted when the firm is led by a managing owner. In this case, ownership and management are unified, leading to the avoidance of agency costs and thus to an increase in value for the firm (Jensen \& Meckling, 1976). Fama and Jensen (1983a and 1983b) extend Jensen and Meckling’s work by arguing that despite agency threats occurring from the separation of ownership and management, an increase in efficiencies may exceed agency costs (Fama \& Jensen, 1983a; Fama \& Jensen, 1983b). These efficiencies are caused by specialisation at various levels and the willingness to take risks due to efficient risk sharing.

An alignment of ownership and management is not always the case in reality. Thus, attempts are made to inhibit decision-making that is not in full congruence with the goals of the firm. These controls include the installation of information and monitoring systems and contracts to ensure that firm goals are the main priority of all actors. The idea of information asymmetries has also been associated with the problem of moral hazard. In this case, the agent pursues own goals and follows own preferences instead of considering the firm's risks and goals. Another problem associated with this approach is adverse selection, which means that the agent might hide or not tell the truth about his or her own abilities and interests for a contractual relationship, causing the principal to be unsure about these abilities and thus select an agent based upon the information available (Eisenhardt, 1989; Jensen \& Meckling, 1976).

Eisenhardt (1989) specifies the agency theory approach through seven characteristics (see Table 4.1). First, the key idea of agency theory is to understand the problem of agency threats in principal-agent relationships. These relationships between the owner/s (principal) and manager/s (agent) should reflect the efficient organisation of information and risk-bearing costs. Second, this situation occurs on the level of the principal and the agent as the unit of analysis. Third, the approach is based on the assumptions that human beings are self- 
interested individualists that act in a rational but bounded manner and avoid risks when taking decisions. Fourth, partial conflicts of contracting relationships arise between the preferences of principals (primarily representing the interests of the firm) and of agents (primarily representing the interests of individuals). The main goal of the firm is to work efficiently, which is the primary effectiveness criterion. However, there are information asymmetries between the principal and the agent, leading to different goals and preferences. Fifth, information can be purchased and traded. Sixth, these information asymmetries lead to the problems of moral hazard (risk willing behaviour of the agent, who is not directly threatened by potential losses) and adverse selection (suboptimal selection of agents due to limited transparency of abilities and interests). Seventh, these problems occur in relationships between principals and agents with different goals and risk preferences. Examples of these organisational phenomena are the compensation of agents, leadership, etc.

Please insert Table 4.1 about here

Table 4.1: Agency theory overview (modified from Eisenhardt, 1989, p. 59)

\section{Agency theory in the family business context}

Agency theory is one of two theories predominantly used in family business research (Chrisman et al., 2010), aside from the resource based view (Barney, 1991; Wernerfelt, 1984). To delimit agency theory from other theoretical approaches, an often opposed and more collectivistic theory from the economic literature is stewardship theory (Davis, Schoorman, \& Donaldson, 1997; e.g., used by Eddleston, Kellermanns, \& Zellweger, 2010). The stewardship perspective addresses the behaviour of controlling family firm owners that behave as far- 
seeing stewards and are guided by superior organisational goals (Sharma, 2004). Several authors discuss the applicability of agency theory in comparison to stewardship theory in family firms and argue that both theories contribute important insights to the knowledge about family firms (Chrisman, Chua, Kellermanns, \& Chang, 2007; Corbetta \& Salvato, 2004; Eddleston \& Kellermanns, 2007; Kraus, Märk, \& Peters, 2011; Le Breton-Miller, Miller, \& Lester, 2011).

Despite its origin in economic theory and finance (Jensen \& Meckling, 1976), the application of agency theory in family business research increasingly shifted from pure economic thinking to the consideration of more altruistic and relational issues (Mustakallio et al., 2002; Schulze et al., 2001). In a similar manner, researchers also argue that agency theory contributes to the development of social exchange theory; this approach considers rewards and costs arising through the relationships in families with regards to family members and their respective interests and behaviours as principals. (Jennings, Breitkreutz, \& James, 2014)

\subsection{Branches of agency theory}

Agency theory in family business research can be divided into three main branches (Shukla, Carney, \& Gedajlovic, 2014). Often known as the principal-agent paradigm (Jensen \& Meckling, 1976), the first branch focuses on the interaction of economic actors. However, family business research also applied and developed the principal-principal approach, which focuses on ownership issues (Morck \& Yeung, 2003), and the behavioural agency model (Wiseman \& Gómez-Mejía, 1998), which focuses on risk preferences (Figure 4.1). All three branches have been further developed by family business research, introducing additional sources of agency costs that are also of great interest to the general management discipline. 
Please insert Figure 4.1 about here

\section{Figure 4.1: Agency theory branches in family business}

\section{Principal-agent branch}

The principal-agent branch is the most common agency theory branch and focuses on information conflicts and asymmetries between the owner (principal) and agent (manager) (Jensen \& Meckling, 1976). Three major sources of agency costs have been found in prior research from this perspective: (1) costs through monitoring agents; (2) costs from aligning the interests of agents with those of the principal; and (3) remaining costs for the non-efficient practice of diverging goals (Shukla et al., 2014). Proponents of this approach argue for the lack of agency costs when ownership and management are aligned. This alignment of ownership and management is often considered to be a requirement for being defined as family firm (Chua et al., 1999; Litz, 1995). However, in family business research, the approach by Jensen and Meckling (1976) is critically discussed and other potential sources of agency costs due to altruism and relational issues are found (Chrisman et al., 2004; Mustakallio et al., 2002; Schulze et al., 2001; Schulze, Lubatkin, \& Dino, 2003b). These sources encompass self-control problems (Jensen, 1994), generous behaviours within the family and their exploitation, as well as the employment of family members instead of more qualified non-family managers (Gómez-Mejía et al., 2001; Schulze et al., 2003b).

Principal-principal branch

This branch of agency theory was developed in financial research by Anderson and Reeb (2003). The principal-principal approach focuses on agency costs arising through conflicting interests when more owners, being equally authorised, or majority and minority shareholders are involved (Gersick, 1997; Schulze, Lubatkin, \& Dino, 2003a), which is usually the case in 
publicly listed family firms (Anderson \& Reeb, 2003). This constellation also raises problems determining who is responsible and has the power to control and make decisions (Morck \& Yeung, 2003). In family firms, this situation can additionally be complicated by the emotional and relational attitudes of the involved family members (Gómez-Mejía, Haynes, Núñez-Nickel, Jacobson, \& Moyano-Fuentes, 2007; Schulze et al., 2003b), which can eventually lead to a suboptimal economic outcome overall (Shukla et al., 2014).

\section{Behavioural agency model (BAM)}

This branch incorporates elements of agency and prospect theories (Kahneman \& Tversky, 1979) and focuses on the fact that family firm owners have different risk preferences than investors in non-family firms (see also the chapter by Kumeto in this book). The concept is based on the assumption that the decision-makers' risk preferences depend on the situation and are not consistent (Wiseman \& Gómez-Mejía, 1998). Being loss-averse suggests that selfinterested individuals are more likely to prefer minimising current losses over maximising future gains (Shukla et al., 2014). For family firm owners, non-economic and family-centred, long-term considerations play a major role, possibly in such a loss-averse risk preference. This way of thinking is incorporated into other approaches evolving from this branch, such as the socioemotional wealth (SEW) concept (Gómez-Mejía et al., 2007). This approach focuses on the importance of the social and emotional interests of family firms (e.g., Berrone, Cruz, \& Gómez-Mejía, 2012; Gómez-Mejía et al., 2007; Gómez-Mejía, Cruz, Berrone, \& Castro, 2011). In this case, agency costs sometimes also stem from prioritising non-financially oriented goals, such as keeping control in the family instead of pursuing more auspicious business opportunities (Chrisman et al., 2004). However, literature discussing the BAM model has not yet agreed on whether risk-taking is indeed lower when family ownership is present (Chrisman \& Patel, 2012; Lim, Lubatkin, \& Wiseman, 2010; Naldi, Nordqvist, Sjöberg, \& Wiklund, 2007; Zahra, Hayton, \& Salvato, 2004; Zellweger \& Sieger, 2012). 


\subsection{Major contributions}

From its origins in financial research, agency theory has become one of the theories predominantly applied and further developed in family business research. Numerous contributions from researchers shaped the current knowledge and usage of agency theory in family business research and beyond. Due to the amount of research that has been done, the ten most cited articles on agency theory in family business in Google Scholar are primarily referred to in this section (Table 4.2) and extended by other influential contributions. The keywords searched for include 'family business'/'family firm' and 'agency theory'/'agency costs.'

Please insert Table 2 about here

Table 4.2: Most cited research on agency theory in family business (own elaboration)

Please insert Table 2 (continued) about here

Table 4.2 (continued): Most cited research on agency theory in family business (own elaboration)

Family business research on agency theory challenges the original assumptions and findings by Jensen and Meckling (1976) and Fama and Jensen (1983a; 1983b), primarily by arguing 
for the consideration of altruistic and relational aspects. Especially Schulze et al. (2001) were among the first to apply agency theory to family firms and emphasise the problems of altruism and self-control when studying family business (Schulze et al., 2001). Altruism here is defined as "a trait that positively links the welfare of an individual to the welfare of others" (Schulze et al., 2001, p.102). In contrast to Jensen and Meckling (1976), Schulze et al. argue for several potential sources of agency costs in family firms, occurring even when ownership and management are aligned, and influence firm behaviour and performance (Schulze et al., 2001).

First, self-control problems occur as few control mechanisms exist (Jensen, 1994). The onthe-job performance of family members is also not as critically controlled. Second, the aspiration of family welfare might cause generous behaviour by family owning managers towards family members. As a result, family members affected by this generosity might exploit that attitude, especially when their personal interests are not congruent with the family’s, creating costs due to moral hazard (see also Kidwell, Kellermanns, \& Eddleston, 2012). Third, adverse selection might create additional costs, for example, by favouring the employment of family members instead of more qualified managers. These family members might additionally misinterpret or even disregard business risks due to their safe family embedment (Gómez-Mejía et al., 2001; Schulze et al., 2003b).

Schulze et al. (2001, 2003b) also contribute scales to measure agency costs in family firms (Table 4.3). The scales developed and applied are a result of individual preferences, causing agency costs that can be related to the mechanisms reducing these costs (Schulze et al., 2001; Schulze et al., 2003b). The variables measured cover (i) the presence of pay incentives to managers, (ii) whether a strategic plan exists and is known, (iii) the entrenchment of the board and, and (iv) whether transfer intentions exist. Control variables, such as firm size or industry, 
are used to reduce variance for the agency cost variables. These variables also support creating and analysing particular groups with "good” or "bad” governance.

Please insert Table 4.3 about here

Table 4.3: Scales for agency costs (based on Schulze et al., 2001, 2003b)

Sieger, Zellweger, and Aquino (2013) offer another solution to avoid agency costs for nonfamily agents by turning them into psychological principals through the transmission of certain rights, such as the right to obtain information or to exercise influence. Their findings show that this strategy has positive effects on performance (Sieger et al., 2013). Based on Chrisman et al. (2007), Sieger, Zellweger, and Aquino also offer an alternative to the measures of Schulze et al. (2001, 2003b). Agency costs are measured as the costs of monitoring mechanisms (such as controlling and reporting) to avoid agency behaviour.

One of the most cited contributions for agency theory in family business research (see Table 4.2 and the section on the principal-principal branch) is Anderson and Reeb (2003). These authors show that family firms may outperform non-family firms depending on family ownership and management, which are related to a reduction in agency costs. The relevant characteristics examined include the age of the firm, the level of family ownership and the family status of the CEO. When the CEO is a family member, for example, performance is shown to be higher (Anderson \& Reeb, 2003). Their work is among the first to compare the performance and agency costs of large family and non-family firms. 
Similarly, Gómez-Mejía et al. (2001) analyse the role of family ties in agency contracts. Furthermore, they focus on the problem of management entrenchment in family firms, which is also referred to in the scales of Schulze et al. (2001). Findings show that management entrenchment, and thus higher agency costs, occur more frequently in family firms compared to non-family firms because relational contracts are often based on emotional values instead of rational criteria, neglecting the sensitivity to risk-taking or weak performance (GómezMejía et al., 2001).

In an early contribution to the family business literature, Daily and Dollinger (1992) compare family-owned and -managed with non-family firms with regards to structural, process and performance dimensions. Their findings show that all of these dimensions are significantly different between the compared groups and especially that performance advantages result from the alignment of ownership and control (Daily \& Dollinger, 1992). The focus of Morck and Yeung’s (2003) conceptual work is on agency problems in larger family firms. These problems are also referred to in, for example, Gómez-Mejía et al. (2001) and Schulze et al. (2001). The problems include certain ownership structures, board entrenchment and moral hazard giving rise to agency costs. In general, their study is among the first to focus on the costs instead of the benefits of being a large family firm, especially when more owners are present (Morck \& Yeung, 2003).

From an agency theory perspective, Carney (2005), in another conceptual contribution, proposes good governance structures for family firms (see also Schulze et al., 2001) that provide a competitive advantage over other types of organisations. According to his findings, family firms have advantages due to (1) organisational authority being in the hands of the family; (2) the family having shared goals that avoid the need for incentives to a certain degree; and (3) family firms being independent of external accountability (Carney, 2005). 
With regards to ownership dispersion in family businesses, Schulze et al. (2003a) analyse the agency consequences of the dispersion of ownership in family firms. Several problems accompany dispersion, which occurs, for example, with an owner-manager or owner-owner structure (with regards to shares). These problems include the issue of free-riding, which is based on information asymmetries and the different incentives of the parties involved (Fama \& Jensen, 1983a; Fama \& Jensen, 1983b). Free-riding means relying on the efforts of other actors instead of realising these efforts oneself. Their findings show that the most severe problems occur when shares are equally divided among a small number of family members (Schulze et al., 2003a; see also Gersick, 1997).

By investigating whether agency costs are higher in family firms than in non-family firms, as for example suggested by Schulze et al. (2001), Chrisman et al. (2004) argue for fewer agency problems in family firms than in non-family firms. Their findings show that control mechanisms (to solve the problem of diverging interests and information asymmetries) are more positively related to performance in non-family firms than in family firms. This finding supports the finding that agency threats are generally lower in family firms. The authors also emphasise the need to consider non-economic goals for family firms when determining agency costs as these might be more relevant than financial performance goals (Chrisman et al., 2004, see also Lee \& Rogoff, 1996).

In a conceptual article about family firms as a heterogeneous group (see also Schulze et al., 2003a), Miller and Le Breton-Miller (2006) categorise family firms by four characteristics: ownership dispersion, leadership, the involvement of family members and the generational perspective. Overall, they suggest aiming at lower agency costs by avoiding free-riding (see also Schulze et al., 2003a) and encouraging the stewardship behaviour of family owning managers. They also find negative effects related to financial performance if a firm is too controlled or too dispersed (see also Massis, Kotlar, Campopiano, \& Cassia, 2013). 


\section{Ideas for future research and implications}

In prior research on agency theory in family firms, most findings refer to the influence of altruistic and relational issues as well as to mechanisms to solve agency problems. Based on these findings, this section aims to develop ideas and possibilities for extending the use of agency theory for family business research, including some weaknesses of the theory, as well as implications for the general management discipline and practice. Differentiation between the heterogeneous structures of family firms is recommended when analysing agency costs. Furthermore, it is proposed that an agency perspective be taken when examining the relationship between entrepreneurial attitudes and performance. Finally, ways to reduce agency costs by monitoring and contractual mechanisms are suggested.

First, drawing on the work of Le Breton-Miller and Miller (2013) and Miller and Le BretonMiller (2006), agency costs can be expected to be a helpful measure for understanding the heterogeneity of family firms (Melin \& Nordqvist, 2007). This heterogeneity describes the family's participation in business in different constellations, from a founder-controlled business to a post-founder business (such as a sibling partnership) to a cousin consortium where more extended family is active (Eddleston \& Kellermanns, 2007; Gersick, 1997; Lim et al., 2010; Massis et al., 2013; Schulze et al., 2003a). When comparing the effects of these management constellations and generational stages of family firms on performance, it is suggested that these effects be measured and explained through agency costs using the scales by Schulze et al. (2001) and Schulze et al. (2003b) as well as Chrisman et al. (2007) and Sieger et al. (2013). It might, for example, be the case that in first- or second-generation firms, agency costs are lower due to the cohesion and shared interests of the founder's family, while in later-generation firms, the emotional distance of cousins might be large, leading to different preferences and thus increased agency costs. 
Second, utilising an agency theory perspective appears to be promising when investigating entrepreneurial attitudes and their influence on performance. For example, the findings (see, e.g., Eisenhardt, 1989; Gómez-Mejía et al., 2007; Schulze et al., 2001) show how ownership and family influence impact risk preferences and business behaviours. Entrepreneurial attitudes form business behaviours and are increasingly being referred to by the Entrepreneurial Orientation (EO) construct (Lumpkin \& Dess, 1996; Miller, 1983) and its dimensions Innovativeness, Proactiveness, Risk-Taking, Autonomy and Competitive Aggressiveness. In general, a entrepreneurially oriented organisation has “a propensity to act autonomously, a willingness to innovate and take risks, and a tendency to be aggressive toward competitors and proactive relative to marketplace opportunities” (Lumpkin \& Dess, 1996, p. 137). These EO dimensions are also found to influence performance. It is proposed that agency costs moderate the effect of a family firms’ EO on performance, as a Risk-Taking attitude in making decisions (Naldi et al., 2007; Zahra, 2005), the degree of competitive behaviour in the market (Gómez-Mejía et al., 2007) or any other EO attitude, depending on the ownership and management distribution. Agency costs as the influencing factor could be identified by the measurements developed in prior family business research (Chrisman et al., 2007; Schulze et al., 2001; Schulze et al., 2003b; Sieger et al., 2013) and might explain differences in performance.

Third, agency theory shows opportunities to further develop contractual and incentive as well as monitoring mechanisms for a reduction in agency costs. The installation of monitoring mechanisms appears to be a meaningful solution to help solve problems, such as asymmetric information. It has been shown that monitoring improves financial performance for both family and non-family managers (Chrisman et al., 2007; Sieger et al., 2013). Contractual mechanisms, such as employment contracts (Gómez-Mejía et al., 2001; Shukla et al., 2014), can be further improved based on empirical research with regards to the usefulness of pay 
incentives to family as well as non-family members (Schulze et al., 2001; Schulze et al., 2003b). These improvements would reduce agency costs and achieve increased professionalization and organisational efficiency for family firms.

The primary weakness of applying agency theory to family business research is its limited measurability. Although Schulze et al. (2001) and Schulze et al. (2003b) provide scales to identify agency costs (see Table 4.3), the measuring items focus on indirect variables indicating potential sources of agency costs. In family firms, it appears to be particularly difficult to measure individual preferences that are guided by relational and altruistic motives and to quantify the costs they cause. These preferences may also rapidly change depending on the situation (see also Wiseman \& Gómez-Mejía, 1998) and thus be difficult to assign to their effects on performance. The approach of Chrisman et al. (2007) and Sieger et al. (2013), measuring agency costs via the costs of monitoring mechanisms instead and aligning individual with firm preferences, does not completely resolve these shortcomings. Tackling these measuring problems might be a promising avenue for future research.

Agency theory is widely used throughout numerous disciplines. Findings from family business research have contributed to build the theory, which is valid beyond family firms, contributing the principal-principal approach, the behavioural agency model and social exchange thinking. Based on these findings, this chapter proposes that the general management discipline also consider altruistic and relational preferences for non-family firms. It is suggested that these preferences can be related to the behaviours of individuals not only within families but also within social groups in general. Social entrepreneurship and also socially oriented firms might profit from this research approach.

This chapter is not without limitations. First, the selection of the ten most cited journal articles as a representation of agency theory in family firms cannot picture the full amount of research that has been performed. Second, the primary focus of this chapter is to present and discuss 
the state of art and future ideas for agency theory in family business. Future research might want to specifically analyse how the different branches of agency theory are transmitted in family firms.

\section{Conclusion}

This chapter discusses how agency theory helps to improve the understanding of organisational structures and management issues in family firms. It explains how family business research applies and develops agency theory to analyse problems and quantify costs arising from the complex structures of family firms, which combine family and business elements. Individual, rational decision-making is integrated with relational, altruistic thinking and thus creates a more complete picture of family firm management. However, it is necessary to extend the knowledge of agency theory in family firms with regards to the heterogeneity of family firms, its impact on the entrepreneurial attitudes of family firms, the effectiveness of contractual mechanisms, and its measurability. 


\section{References}

Anderson, R. C., and Reeb, D. M., (2003), 'Founding-family ownership and firm performance: Evidence from the S\&P 500', The Journal of Finance, 58(3), 13011327.

Barney, J., (1991), 'Special theory forum: The resource-based model of the firm: Origins, implications, and prospects', Journal of Management, 17(1), 99-120.

Berrone, P., Cruz, C., and Gómez-Mejía, L. R., (2012), 'Socioemotional wealth in family firms: Theoretical dimensions, assessment approaches, and agenda for future research', Family Business Review, 25(3), 258-279.

Carney, M., (2005), 'Corporate governance and competitive advantage in family-controlled firms', Entrepreneurship Theory and Practice, 29(3), 249-265.

Chrisman, J. J., Chua, J. H., Kellermanns, F. W., and Chang, E. P. C., (2007), 'Are family managers agents or stewards? An exploratory study in privately held family firms', Family Influences on Firms, 60(10), 1030-1038.

Chrisman, J. J., Chua, J. H., and Litz, R. A., (2004), 'Comparing the agency costs of family and non-family firms: Conceptual issues and exploratory evidence', Entrepreneurship: Theory \& Practice, 28(4), 335-354.

Chrisman, J. J., Kellermanns, F. W., Chan, K. C., and Liano, K., (2010), 'Intellectual foundations of current research in family business: An identification and review of 25 influential articles', Family Business Review, 23(1), 9-26.

Chrisman, J. J., and Patel, P. C., (2012). 'Variations in R\&D investments of family and nonfamily firms: Behavioral agency and myopic loss aversion perspectives', Academy of Management Journal, 55(4), 976-997. 
Chua, J. H., Chrisman, J. J., and Sharma, P., (1999), 'Defining the family business by behavior', Entrepreneurship: Theory \& Practice, 23(4), 19-39.

Corbetta, G., and Salvato, C., (2004), 'Self-serving or self-actualizing? Models of man and agency costs in different types of family firms: A commentary on "Comparing the agency costs of family and non-family firms: Conceptual issues and exploratory evidence”', Entrepreneurship: Theory \& Practice, 28(4), 355-362.

Daily, C. M., and Dollinger, M. J., (1992). 'An empirical examination of ownership structure in family and professionally managed firms', Family Business Review, 5(2), 117-136.

Davis, J. H., Schoorman, F. D., and Donaldson, L., (1997), 'Toward a stewardship theory of management', Academy of Management Review, 22(1), 20-47.

Eddleston, K. A., and Kellermanns, F. W., (2007), 'Destructive and productive family relationships: A stewardship theory perspective', Journal of Business Venturing, 22(4), 545-565.

Eddleston, K. A., Kellermanns, F. W., and Zellweger, T. M., (2010), 'Exploring the entrepreneurial behavior of family firms: Does the stewardship perspective explain differences?', Entrepreneurship Theory and Practice, 36(2), 347-367.

Eisenhardt, K. M., (1989), 'Agency theory: An assessment and review', The Academy of Management Review, 14(1), 57-74.

Fama, E. F., and Jensen, M. C., (1983a), 'Agency problems and residual claims', Journal of Law and Economics, 26(2), 327-349.

Fama, E. F., and Jensen, M. C., (1983b), 'Separation of Ownership and Control', Journal of Law and Economics, 26(2), 301-325.

Gersick, K. E., (1997), Generation to generation: Life cycles of the family business, Boston: Harvard Business School Press. 
Gómez-Mejía, L. R., Cruz, C., Berrone, P., and Castro, J. d., (2011), 'The bind that ties: Socioemotional wealth preservation in family firms', The Academy of Management Annals, 5(1), 653-707.

Gómez-Mejía, L. R., Haynes, K. T., Núñez-Nickel, M., Jacobson, K. J. L., and MoyanoFuentes, J., (2007), 'Socioemotional wealth and business risks in family-controlled firms: Evidence from Spanish olive oil mills', Administrative Science Quarterly, 52(1), $106-137$.

Gómez-Mejía, L. R., Nuñez-Nickel, M., and Gutierrez, I., (2001), 'The role of family ties in agency contracts', Academy of Management Journal, 44(1), 81-95.

Jennings, J. E., Breitkreuz, R. S., and James, A. E., (2014), 'Theories from family science: A review and roadmap for family business research', In Melin, L., Nordqvist, M. and Sharma, P. (eds.), Sage Handbook of Family Business Studies, Thousand Oaks: Sage Publications Ltd., pp. 25-46.

Jensen, M. C., (1994), 'Self-Interest, altruism, incentives, and agency theory', Journal of Applied Corporate Finance, 7(2), 40-45.

Jensen, M. C., and Meckling, W. H., (1976), 'Theory of the firm: Managerial behavior, agency costs and ownership structure', Journal of Financial Economics, 3(4), 305360.

Kahneman, D., and Tversky, A., (1979), 'Prospect theory: An analysis of decision under risk', Econometrica, 47(2), 263-291.

Kidwell, R. E., Kellermanns, F. W., and Eddleston, K. A., (2012), 'Harmony, justice, confusion, and conflict in family firms: Implications for ethical climate and the "Fredo Effect”', Journal of Business Ethics, 106(4), 503-517. 
Kraus, S., Märk, S., and Peters, M., (2011). 'The influences of family on the everyday business of a family firm entrepreneur', International Journal of Entrepreneurship and Small Business, 12(1), 82-100.

Le Breton-Miller, I., and Miller, D., (2013), 'Socioemotional wealth across the family firm life cycle: A commentary on "Family business survival and the role of boards”', Entrepreneurship Theory and Practice, 37(6), 1391-1397.

Le Breton-Miller, I., Miller, D., and Lester, R. H., (2011), 'Stewardship or agency? A social embeddedness reconciliation of conduct and performance in public family businesses', Organization Science, 22(3), 704-721.

Lee, M.-S., and Rogoff, E. G., (1996). 'Research note: Comparison of small businesses with family participation versus small businesses without family participation: An investigation of differences in goals, attitudes, and family/business conflict', Family Business Review, 9(4), 423-437.

Lim, E. N. K., Lubatkin, M. H., and Wiseman, R. M., (2010), 'A family firm variant of the behavioral agency theory', Strategic Entrepreneurship Journal, 4(3), 197-211.

Litz, R. A., (1995), 'The family business: Toward definitional clarity', Family Business Review, 8(2), 71-81.

Lumpkin, G. T., and Dess, G. G., (1996), 'Clarifying the entrepreneurial orientation construct and linking it to performance', Academy of Management Review, 21(1), 135-172.

Massis, A. d., Kotlar, J., Campopiano, G., and Cassia, L., (2013), 'Dispersion of family ownership and the performance of small-to-medium size private family firms', Journal of Family Business Strategy, 4(3), 166-175.

Melin, L., and Nordqvist, M., (2007), 'The reflexive dynamics of institutionalization: the case of the family business', Strategic Organization, 5(3), 321-333. 
Miller, D., (1983), 'The Correlates of Entrepreneurship in Three Types of Firms', Management Science, 29(7), 770-791.

Miller, D., and Le Breton-Miller, I., (2006), 'Family governance and firm performance: Agency, stewardship, and capabilities', Family Business Review, 19(1), 73-87.

Morck, R., and Yeung, B., (2003), 'Agency problems in large family business groups', Entrepreneurship: Theory \& Practice, 27(4), 367-382.

Mustakallio, M., Autio, E., and Zahra, S. A., (2002), 'Relational and contractual governance in family firms: Effects on strategic decision making', Family Business Review, 15(3), 205-222.

Naldi, L., Nordqvist, M., Sjöberg, K., and Wiklund, J., (2007), 'Entrepreneurial orientation, risk taking, and performance in family firms', Family Business Review, 20(1), 33-47.

Nordqvist, M., Habbershon, T. G., and Melin, L., (2008), 'Transgenerational entrepreneurship: Exploring entrepreneurial orientation in family firms', In Landström, H., Smallbone, D., Crijns, H. and Laveren, E. (eds.), Entrepreneurship, sustainable growth and performance. Frontiers in European entrepreneurship research Cheltenham, UK; Northampton, MA: Edward Elgar, pp. 93-116.

Poppo, L., and Zenger, T., (2002), 'Do formal contracts and relational governance function as substitutes or complements?', Strategic Management Journal, 23(8), 707-725.

Schulze, W. S., Lubatkin, M. H., and Dino, R. N., (2003a), 'Exploring the agency consequences of ownership dispersion among the directors of private family firms', The Academy of Management Journal, 46(2), 179-194.

Schulze, W. S., Lubatkin, M. H., and Dino, R. N., (2003b), 'Toward a theory of agency and altruism in family firms', Journal of Business Venturing, 18(4), 473-490. 
Schulze, W. S., Lubatkin, M. H., Dino, R. N., and Buchholtz, A. K., (2001), 'Agency relationships in family firms', Organization Science, 12(2), 99-116.

Sharma, P., (2004), 'An overview of the field of family business studies: Current status and directions for the future', Family Business Review, 17(1), 1-36.

Sharma, P., Chrisman, J. J., and Chua, J. H., (1997), 'Strategic management of the family business: Past research and future challenges', Family Business Review, 10(1), 1-35.

Shukla, P. P., Carney, M., and Gedajlovic, E., (2014), 'Economic theories of family firms', In Melin, L., Nordqvist, M. and Sharma, P. (eds.), Sage Handbook of Family Business Studies Thousand Oaks: Sage Publications Ltd, pp. 100-118.

Sieger, P., Zellweger, T., and Aquino, K., (2013), 'Turning agents into psychological principals: Aligning interests of non-owners through psychological ownership', Journal of Management Studies, 50(3), 361-388.

Wernerfelt, B., (1984), 'A resource-based view of the firm', Strategic Management Journal, 5(2), 171-180.

Wiseman, R. M., and Gómez-Mejía, L. R., (1998), 'A behavioral agency model of managerial risk taking', Academy of Management Review, 23(1), 133-153.

Zahra, S. A., (2005), 'Entrepreneurial risk taking in family firms', Family Business Review, 18(1), 23-40.

Zahra, S. A., Hayton, J. C., and Salvato, C., (2004), 'Entrepreneurship in family vs. nonfamily firms: A Resource-based analysis of the effect of organizational culture', Entrepreneurship Theory and Practice, 28(4), 363-381.

Zellweger, T., and Sieger, P., (2012), 'Entrepreneurial orientation in long-lived family firms', Small Business Economics, 38(1), 67-84. 
Table 4.1: Agency theory overview

\begin{tabular}{|c|c|}
\hline Key idea & $\begin{array}{l}\text { Principal-agent relationships should reflect efficient } \\
\text { organization of information and risk-bearing costs }\end{array}$ \\
\hline Unit of analysis & Contract between principal and agent \\
\hline \multirow[t]{3}{*}{ Human assumptions } & Self-Interest \\
\hline & Bounded rationality \\
\hline & Risk aversion \\
\hline \multirow{3}{*}{$\begin{array}{l}\text { Organizational } \\
\text { assumptions }\end{array}$} & Partial goal conflict among participants \\
\hline & Efficiency as the effectiveness criterion \\
\hline & Information asymmetry between principal and agent \\
\hline Information assumptions & Information as a purchasable commodity \\
\hline \multirow[t]{2}{*}{ Contracting problems } & Agency (moral hazard and adverse selection) \\
\hline & Risk sharing \\
\hline Problem domain & $\begin{array}{l}\text { Relationships in which the principal and agent have partly } \\
\text { differing goals and risk preferences (e.g. compensation, } \\
\text { leadership, etc.) }\end{array}$ \\
\hline
\end{tabular}

Source: Modified from Eisenhardt (1989, p. 59)

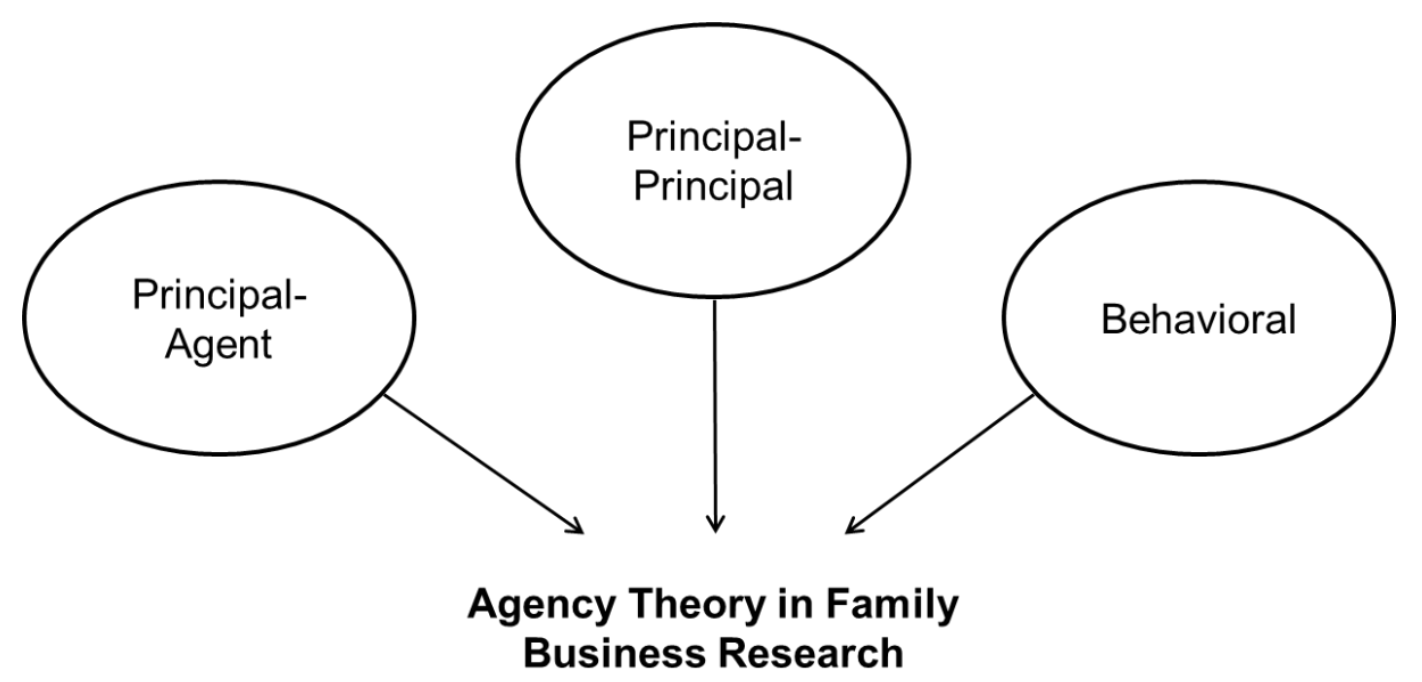

Figure 4.1: Agency theory branches in family business research (see also Shukla et al., 
Table 4.2: Most cited research on agency theory in family business

\begin{tabular}{|c|c|c|c|c|c|}
\hline Author(s)/Year & Journal & Citations & \begin{tabular}{|l|} 
Purpose/ \\
Main agency theory \\
branch background
\end{tabular} & Method/Sample & Key findings/Conclusions \\
\hline $\begin{array}{l}\text { Anderson and Reeb } \\
\text { (2003) }\end{array}$ & $\begin{array}{l}\text { Journal of } \\
\text { Finance }\end{array}$ & 2208 & $\begin{array}{l}\text { Investigate the relation } \\
\text { between founding- } \\
\text { family ownership and } \\
\text { firm performance/ } \\
\text { principal-principal }\end{array}$ & $\begin{array}{l}\text { Quantitative } \\
\text { (secondary data)/ } \\
\text { S\&P } 500 \text { firms } \\
\text { (family and non- } \\
\text { family) }\end{array}$ & $\begin{array}{l}\text { Family firms perform better } \\
\text { than non-family firms, } \\
\text { especially when family } \\
\text { members serve as CEO. This } \\
\text { is due to the efficiency of } \\
\text { family ownership. }\end{array}$ \\
\hline $\begin{array}{l}\text { Schulze, Lubatkin, } \\
\text { Dino and Buchholtz } \\
\text { (2001) }\end{array}$ & $\begin{array}{l}\text { Organization } \\
\text { Science }\end{array}$ & 1069 & \begin{tabular}{|l|} 
Study whether owner \\
management \\
necessarily eliminates \\
the agency costs of \\
ownership/ \\
principal-agent
\end{tabular} & $\begin{array}{l}\text { Quantitative } \\
\text { (survey)/ } 1376 \\
\text { U.S. family firms }\end{array}$ & $\begin{array}{l}\text { Family firms face problems of } \\
\text { self-control, adverse selection, } \\
\text { altruism and moral hazard. } \\
\text { These may offset family firm } \\
\text { advantages auch as the } \\
\text { alignment of ownership and } \\
\text { management or commitment. }\end{array}$ \\
\hline $\begin{array}{l}\text { Gomez-Mejía, } \\
\text { Núñez-Nickel and } \\
\text { Gutierrez (2001) }\end{array}$ & $\begin{array}{l}\text { Academy of } \\
\text { Management } \\
\text { Journal }\end{array}$ & 683 & $\begin{array}{l}\text { Analyze the role of } \\
\text { family ties in agency } \\
\text { contracts/ } \\
\text { behavioral and } \\
\text { principial-principal }\end{array}$ & $\begin{array}{l}\text { Quantitative } \\
\text { (longitudinal } \\
\text { secondary data)/ } \\
276 \text { Spanish news- } \\
\text { papers (family and } \\
\text { non-family firms) } \\
\end{array}$ & $\begin{array}{l}\text { Emotional rather than rational } \\
\text { criteria govern the terms of } \\
\text { exchange. Family contracting } \\
\text { is more likely to increase } \\
\text { agency costs as a result of } \\
\text { executive entrenchment. }\end{array}$ \\
\hline $\begin{array}{l}\text { Daily and Dollinger } \\
\text { (1992) }\end{array}$ & $\begin{array}{l}\text { Family } \\
\text { Business } \\
\text { Review }\end{array}$ & 554 & \begin{tabular}{|l|} 
Empirically examine \\
the ownership \\
structure in family and \\
non-family firms/ \\
principal-agent
\end{tabular} & $\begin{array}{l}\text { Quantitative } \\
\text { (survey)/ } 186 \text { U.S. } \\
\text { manufacturing } \\
\text { firms (family and } \\
\text { non-family firms) }\end{array}$ & $\begin{array}{l}\text { Performance advantages of } \\
\text { family firms result from the } \\
\text { alignment of ownership and } \\
\text { control. }\end{array}$ \\
\hline $\begin{array}{l}\text { Schulze, Lubatkin } \\
\text { and Dino (2003b) }\end{array}$ & $\begin{array}{l}\text { Journal of } \\
\text { Business } \\
\text { Venturing }\end{array}$ & 545 & \begin{tabular}{|l|} 
Explain why family \\
firms use pay \\
incentives and develop \\
theory that predicts \\
when this is beneficial/ \\
principal-agent and \\
behavioral
\end{tabular} & $\begin{array}{l}\text { Quantitative } \\
\text { (survey)/ } 883 \text { U.S. } \\
\text { family firms }\end{array}$ & $\begin{array}{l}\text { Altruism influences agency } \\
\text { relationships in family firms. } \\
\text { Pay incentives to family firm } \\
\text { managers are beneficial for } \\
\text { firm performance under certain } \\
\text { circumstances. }\end{array}$ \\
\hline $\begin{array}{l}\text { Morck \& Yeung } \\
\text { (2003) }\end{array}$ & $\begin{array}{l}\text { Entrepreneur- } \\
\text { ship, Theory \& } \\
\text { Practice }\end{array}$ & 515 & $\begin{array}{l}\text { Discuss agency } \\
\text { problems of large } \\
\text { family firms/ } \\
\text { principal-principal }\end{array}$ & Conceptual & $\begin{array}{l}\text { Agency costs in family firms } \\
\text { are created from ownership } \\
\text { structures (especially with } \\
\text { multiple owners), board en- } \\
\text { trenchment and moral hazard. }\end{array}$ \\
\hline Carney (2005) & $\begin{array}{l}\text { Entrepreneur- } \\
\text { ship, Theory \& } \\
\text { Practice }\end{array}$ & 490 & \begin{tabular}{|l|} 
Identify the \\
competitive advantage \\
of family firms from \\
an agency theory \\
perspective/ \\
principal-agent
\end{tabular} & Conceptual & $\begin{array}{l}\text { Competitive advantage of } \\
\text { family firms due to corporate } \\
\text { governance elements: (1) } \\
\text { organizational authority is in the } \\
\text { hands of the family; (2) the } \\
\text { family has shared goals that } \\
\text { avoid the need for incentives; } \\
\text { (3) family firms are indepen- } \\
\text { dent to external accountability. }\end{array}$ \\
\hline $\begin{array}{l}\text { Schulze, Lubatkin } \\
\text { and Dino (2003a) }\end{array}$ & \begin{tabular}{|l} 
Academy of \\
Management \\
Journal
\end{tabular} & 439 & \begin{tabular}{|l|} 
Explore the agency \\
consequences of \\
ownership dispersion \\
among the directors of \\
private family firms/ \\
principal-principal and \\
principal-agent
\end{tabular} & $\begin{array}{l}\text { Quantitative } \\
\text { (survey)/ } 1464 \\
\text { U.S. family firms }\end{array}$ & $\begin{array}{l}\text { Ownership dispersion causes } \\
\text { the problem of free-riding } \\
\text { (based on information } \\
\text { asymmetries), especially when } \\
\text { shares are equally divided } \\
\text { among a small number of } \\
\text { family members. }\end{array}$ \\
\hline
\end{tabular}




\begin{tabular}{|c|c|c|c|c|c|}
\hline $\begin{array}{l}\text { Chrisman, Chua } \\
\text { and Litz (2004) }\end{array}$ & $\begin{array}{l}\text { Entrepreneur- } \\
\text { ship, Theory \& } \\
\text { Practice }\end{array}$ & 424 & $\begin{array}{l}\text { Compare the agency } \\
\text { costs of family and } \\
\text { non-family firms/ } \\
\text { principal-agent and } \\
\text { behavioral }\end{array}$ & $\begin{array}{l}\text { Quantitative } \\
\text { (survey)/ } 1241 \\
\text { U.S. firms (family } \\
\text { and non-family) }\end{array}$ & $\begin{array}{l}\text { Due to less necessity of control } \\
\text { mechanisms in family firms, } \\
\text { overall agency threats are less } \\
\text { serious than those in non- } \\
\text { family firms. Also, non- } \\
\text { economic performance goals } \\
\text { of family firms need to be } \\
\text { considered. }\end{array}$ \\
\hline $\begin{array}{l}\text { Miller and } \\
\text { Le Breton-Miller } \\
\text { (2006) }\end{array}$ & $\begin{array}{l}\text { Family } \\
\text { Business } \\
\text { Review }\end{array}$ & 373 & $\begin{array}{l}\text { Reflect on pecularities } \\
\text { of family governance } \\
\text { and firm performance } \\
\text { from agency and } \\
\text { stewardship } \\
\text { perspectives/ } \\
\text { principal-agent and } \\
\text { behavioral }\end{array}$ & Conceptual & $\begin{array}{l}\text { Family firms are characterized } \\
\text { by ownership dispersion, } \\
\text { leadership, involvement of } \\
\text { family members and } \\
\text { generational perspective. Goals } \\
\text { should be to avoid free-riding, } \\
\text { too much control and too much } \\
\text { dispersion. This all causes } \\
\text { agency costs and a negative } \\
\text { impact on performance. }\end{array}$ \\
\hline
\end{tabular}

\section{Table 4.3: Scales for agency costs}

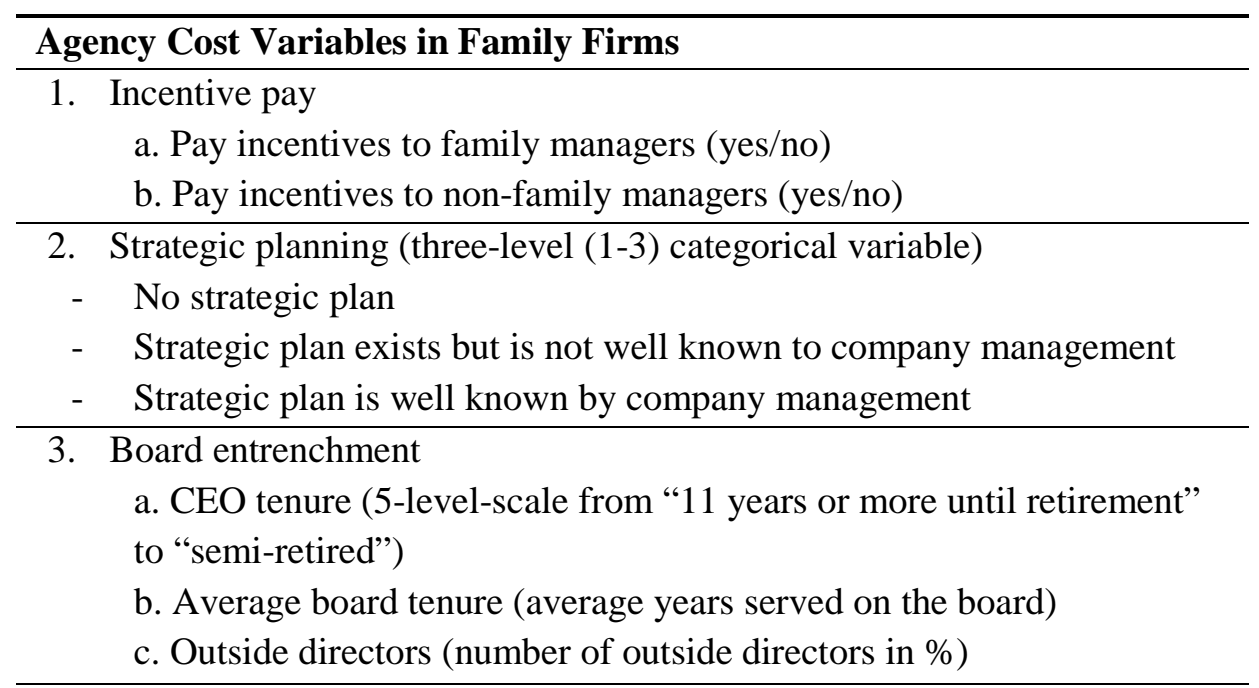

4. Transfer intentions (yes/no)

Source: Based on Schulze et al., (2001, 2003b) 